INTERNATIONAL JOURNAL OF RESEARCHES IN BIOSCIENCES, AGRICULTURE AND TECHNOLOGY (C) VISHWASHANTI MULTIPURPOSE SOCIETY (Global Peace Multipurpose Society) R. No. MH-659/13(N)

\title{
EFFECT OF GA 3 ON IN VITRO PROPAGATION OF WHITE MARIGOLD
}

\author{
S. Patil ${ }^{1}$, R. D. Deotale ${ }^{2}$, V. Kalamkar ${ }^{3}$, S. Patil ${ }^{4}$ and D. J. Jiotode ${ }^{5}$ \\ 1,5College of Agriculture, Nagpur \\ ${ }^{2}$ Botany Section, College of Agriculture, Nagpur \\ 3Junior Research Assistant, Botany Section, College of Agriculture, Nagpur \\ ${ }^{4}$ P. G. Student
}

\begin{abstract}
Experiment was carried out during 2014-15 at Botany Section, College of Agriculture, Nagpur to identify an in vitro protocol for the propagation of white marigold and also to study the effect of gibrellic acid on in vitro propagation. The explants axillary buds were used for culturing in the MS basal fortified with growth regulator like $\mathrm{BAP}$ and IAA in different concentrations along with $\mathrm{GA}_{3}(14.43 \mu \mathrm{M})$ and without $\mathrm{GA}_{3} . \mathrm{GA}_{3}$ played significant role in the induction of shoot buds as well as suppressing callus formation. The axillary bud explants responded well for all the traits studied. The treatment T16 (MS + BAP 4.44 $\mu \mathrm{m}+$ IAA $2.84 \mu \mathrm{m}+\mathrm{GA}_{3} 14.43 \mu \mathrm{m}$ ) and T11 (MS + BAP $4.44 \mu \mathrm{m}+\mathrm{GA}_{3} 14.43 \mu \mathrm{m}$ ) exhibited good performance for response to shoot initiation (\%), days to shoot initiation, number of shoots culture ${ }^{-1}$ and number of shoots elongated culture ${ }^{-1}$. Average performance recorded for response of shoot initiation(\%) was $68.61 \%$, days to shoot initiation was 14.62 days, number of shoots culture ${ }^{-1}$ was 5.01 , number of shoots elongated culture ${ }^{-1}$ was 3.49 , response of root initiation (\%) was 57.58 and days to root initiation was 7.81. The shoot propagated from axillary bud were found to root well in treatment T5 (MS+ NAA $0.27 \mu \mathrm{m})$ and

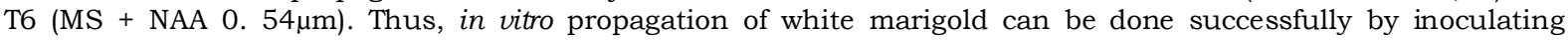

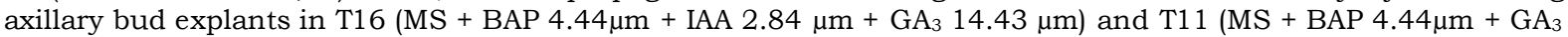
$14.43 \mu \mathrm{m}$ ) for shoot induction and proliferation followed by transferring the shoots to T5 (MS+ NAA $0.27 \mu \mathrm{m})$ for rooting.
\end{abstract}

Key words:- White marigold, shoot tip culture, in vitro propagation

\section{Introduction:}

Marigold (Tagetes erecta L.) is an Asteraceous plant of industrial and medicinal importance. This herbaceous plant is native to Mexico, where it is used in traditional medicine and for ornamental purposes. It has been reported that this plant contains bioactive compounds that exhibit nematicidal, fungicidal and insecticidal activity (Vasudevan et al., 1977). The flowers are utilized as a source of pigments for food coloring in industry mainly of poultry skin and eggs (Delgado-Vargas et al. 2000). Lutein is the main pigment in marigold flowers. It is synthesized through the isoprenoid pathway, which could be modified to produce new high-value-added carotenoids or to increase production for pigmentation purposes and phytochemical functionality. The wide range of uses of this plant underlines the importance of establishing a reliable plant regeneration system for further genetic manipulation.

There are few reports on marigold tissue culture. These reports use a wide range of explants sources, different types and combinations of plant growth regulators and results in organ or embryo formation (Kothari and Chandra, 1984; Belarmino et al., 1992; Bespalhok and Hattori, 1998; Misra and Datta, 1999). However, the reproducibility of the results was poor. Hence, in this study an attempt was made to develop a protocol for direct differentiation of shoots from axillary buds of white marigold without any intervening callus. This protocol will be useful for large- scale clonal multiplication as well as for future transformation studies.

\section{Materials and Methods:}

Experiment was carried out during 2014-15 at Botany Section, College of Agriculutre, Nagpur. The explants axillary buds collected from the white marigold at the active stage of growth before flowering were used as source material. The plant source for collecting the explants were available at Botanical Garden, College of Agriculture, Nagpur. The explants were surface sterilized with $0.1 \% \quad \mathrm{HgCl}_{2}$ for 5 minutes followed by 4-5 washings with distilled water and sterile water. After surface sterilization the explants of $1-1.5 \mathrm{~cm}$ were cut and inoculated on MS basal media fortified with different concentrations of BAP, IAA along with or without $\mathrm{GA}_{3}$. The media was solidified with $0.8 \%$ agar and the $\mathrm{pH}$ was adjusted to 5.8. For observing morphogenic response of explants, culture were maintained at $25 \pm 20 \mathrm{C}$ with a photoperiod of $16 \mathrm{hrs}$. light and $8 \mathrm{hrs}$. dark. The multiple shoots were transferred to MS media with different concentrations of IAA, IBA, NAA any one for rooting. Observations were recorded periodically after inoculation on response to shoot initiation (\%), days for shoot initiation, number of shoots culture-1, number of shoots elongated culture ${ }^{-1}$, response on root initiation (\%) and days for root initiation. The experiment was conducted in CRD and 10 aliquots having one explants of each were used for recording observations for the analysis of variance, the 
mean values of 5 aliquots were used in duplex for statistical analysis.

\section{Results and Discussion:}

The results on shoot initiation, days to shoot initiation and number of shoots culture-1 and number of shoot elongated culture-1 are presented in table 1. It was observed from the data that explants established in all the treatments. The overall mean response of shoot initiation to culture media was observed to be $68.61 \%$. This indicates that the explants axillary bud had high potential to induce shoot buds which may be due to the fact that the axillary bud tissue culture system stimulate the genesis of shoots from newly formed and preexisting meristematic regions of nodal tissue. Misra and Datta (2001) and Vanagas et al.(2002) also reported the superior efficiency of axillary bud in marigold. The response of shoot initiation expressed in per cent ranged from $44.50 \%$ (T3$\mathrm{MS}+\mathrm{BAP} 8.88 \mu \mathrm{m}$ ) to $99.50 \%$ (T16- MS + BAP $4.44 \mu \mathrm{m}+$ IAA $\left.2.84 \mu \mathrm{m}+\mathrm{GA}_{3} 14.43 \mu \mathrm{m}\right)$. The treatment T16 (MS + BAP 4.44 $\mu \mathrm{m}+$ IAA $2.84 \mu \mathrm{m}$ $\left.+\mathrm{GA}_{3} 14.43 \mu \mathrm{m}\right)$ showed maximum percentage of $99.50 \%$ response followed by T11- MS + BAP $4.44 \mu \mathrm{m}+\mathrm{GA}_{3} 14.43 \mu \mathrm{m}(99 \%)$, and $\mathrm{T} 14 \mathrm{MS}+$ BAP $2.22 \mu \mathrm{m}+$ IAA $2.84 \mu \mathrm{m}+\mathrm{GA}_{3} 14.43 \mu \mathrm{m}$ $(82 \%)$ and were observed as most effective treatment for response of shoot initiation.

$\mathrm{GA}_{3}$ played a very significant role for the induction of shoot buds. The differentiation of shoot buds was direct without any associated callus. $\mathrm{GA}_{3}$ played a very significant role for the induction of shoot buds. Explants of Tagetes had a tendency to form callus which was enhanced in the presence of auxins. In the present experiment $\mathrm{GA}_{3}(14.43 \mathrm{mM})$ and $\mathrm{BAP}$ $(4.44 \mathrm{mM})$ in the absence or presence of auxin were found to induce shoot bud differentiation. The differentiation of shoot buds was direct without any associated callus. In this optimum treatment an average of 3.30 to 7.80 shoot buds differentiated, mainly from the margins and rarely from the cut ends, within 2 weeks of incubation (Table 1). Analysis of variance (ANOVA) indicated significant differences among the treatments. On further increasing the concentration of $\mathrm{GA}_{3}$ (from 28.9 to $57.7 \mathrm{mM}$ ), the explants turned yellowish brown in color without any differentiation of shoots and hence the data of these treatments are not included in the study. $\mathrm{GA}_{3}$ had also been found conducive for in vitro shoot regeneration in floret explants of chrysanthemum (Chakrabarty et al., 2000). In this context Sekioka and Tanaka (1981) are of the opinion that $\mathrm{GA}_{3}$ can act as a replacement for auxin in shoot induction, and thus a ratio of cytokinin \pm GA may be decisive for differentiation in certain plant tissues.

The axillary bud produced shoot bud by the sprouting of axillary bud by the formation of adventious bud. The data on days to shoot initiation indicated significant variation for this trait among the treatments. On an average shoot initiation in white marigold started 14.62 (@15days) days after inoculation in the present study. However, minimum number of days required for shoot initiation was observed in the treatment T15- MS + BAP 4.44 $\mu \mathrm{m}+$ IAA $1.42 \mu \mathrm{m}$ $+\mathrm{GA}_{3} 14.43 \mu \mathrm{m}$ (7.79 days) followed by T12- MS + BAP 8.88 $\mu \mathrm{m}+\mathrm{GA}_{3} 14.43 \mu \mathrm{m}$ (8.25 days), and $\mathrm{T} 10-\mathrm{MS}+\mathrm{BAP} 2.22 \mu \mathrm{m}+\mathrm{GA}_{3} 14.43 \mu \mathrm{m}(9.07$ days). In accordance to this result Mishra and Datta (2001) obtained shoot buds from the explants after two weeks of inoculation in marigold. The overall mean number of shoot buds obtained was 5.01 culture-1. The maximum number of 7.80 shoot buds were obtained from axillary bud explants in treatment T16 (MS + BAP 4.44 $\mu \mathrm{m}+$ IAA $2.84 \mu \mathrm{m}+\mathrm{GA}_{3}$ $14.43 \mu \mathrm{m})$ followed by $\mathrm{T} 11-\mathrm{MS}+\mathrm{BAP} 4.44 \mu \mathrm{m}+$ $\mathrm{GA}_{3} 14.43 \mu \mathrm{m}$ (7.34), T12- MS+ BAP 8.88 $\mu \mathrm{m}+$ $\mathrm{GA}_{3} 14.43 \mu \mathrm{m}$ (6.57) and $\mathrm{T} 15-\mathrm{MS}+\mathrm{BAP}$ $4.44 \mu \mathrm{m}+$ IAA $1.42 \mu \mathrm{m}+\mathrm{GA}_{3} 14.43 \mu \mathrm{m}$ (6.15). The shoot buds when allowed to elongate and develop into shoots on the same shoot differentiation media it was observed that all buds did not develop into an elongated shoot. The average number of shoot elongated was observed to be 3.49 shoots culture-1. The maximum number of shoots elongated was observed to be 4.94 shoot in T16 (MS + BAP $4.44 \mu \mathrm{m}+$ IAA $\left.2.84 \mu \mathrm{m}+\mathrm{GA}_{3} 14.43 \mu \mathrm{m}\right)$ followed by 4.92 in $\mathrm{T} 11\left(\mathrm{MS}+\mathrm{BAP} 4.44 \mu \mathrm{m}+\mathrm{GA}_{3} 14.43\right.$ $\mu \mathrm{m})$ and 4.57 in $\mathrm{T} 12\left(\mathrm{MS}+\mathrm{BAP} 8.88 \mu \mathrm{m}+\mathrm{GA}_{3}\right.$ $14.43 \mu \mathrm{m})$. Differentiation of shoots of white marigold was achieved in a combination T16 (MS + BAP $4.44 \mu \mathrm{m}+$ IAA $2.84 \mu \mathrm{m}+\mathrm{GA}_{3}$ $14.43 \mu \mathrm{m})$. When the concentration of BAP was increased upto to $8.88 \mu \mathrm{m}$, it became supraoptimal for the explants to differentiate, as they showed hyperhydricity without any further increase in the number of shoots. This problem was also reported by Mishra and Datta (2001). Bhargava et al. (2013) also reported significant improvement in shoot proliferation with the use of growth hormones and linear increase in number of shoots with increased concentration of cytokinins and their combinations. They also reported that MS medium supplemented with $4 \mathrm{mgl}^{-1}$ BAP and $2 \mathrm{mgl}^{-1}$ kinetin was found optimum for proliferation of quality shoots in gerbera. When the differentiated shoots were 
kept in the same regeneration medium, there was no further proliferation of shoots. Therefore, the shoots were subcultured twice in MS media with low concentration of BAP $(1.1 \mu \mathrm{m})$ along with $\mathrm{GA}_{3}(14.43 \mu \mathrm{m})$ to get elongated shoots for transferring for rooting.

The roots formed occasionally on proliferated shoots did not help establishment of the plants in soil. Therefore, isolated shoots were excised and rooted using MS media containing different concentrations of IAA, IBA and NAA with MS media. Average response of root initiation over the treatments was observed to be $57.58 \%$ (Table 2). The highest response for root initiation was observed in treatment $\mathrm{T} 5$ (MS + NAA $0.27 \mu \mathrm{m})$ with $81 \%$ followed by $\mathrm{T} 6$ (MS+ NAA $0.54 \mu \mathrm{m})$ with $68.50 \%$. When NAA was used for root induction 68.50 to $81 \%$ rooting was achieved,, whereas using IAA and IBA the rooting was 42.50 to $57.50 \%$ but associated with callusing and vitrification of shoot. Average number of days required for root initiation was 7.81 days $\cong 8$ days) which indicates that in marigold root initiation can start 8 days after transferring shoots for rooting. In accordance to this result, Son et al. (2011) also reported that MS medium supplemented with $2 \mathrm{mgl}^{-1}$ NAA was found to be the best medium for in vitro rooting of shoots in gerbera. In contrary to this Mishra and Dutta (2001) reported $100 \%$ rooting when
NAA was used and when IAA and IBA were used the rooting they obtained were $100 \%$ but associated with some callusing and vitrification of shoots. The rooted plants were transferred to cups containing sterilized potting mixture for hardening. The percentage survival of the plantlets was observed to be only $40 \%$ when estimated over the rooted plantlets obtained from all the treatments used for root initiation.

It can be inferred from this study that, the axillary bud explants responded well for all the traits studied. The treatment T16 (MS + BAP $4.44 \mu \mathrm{m}+$ IAA $\left.2.84 \mu \mathrm{m}+\mathrm{GA}_{3} 14.43 \mu \mathrm{m}\right)$ and

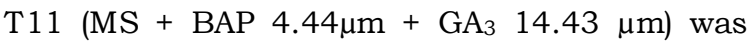
found to exhibit good performance for response to shoot initiation (\%), days to shoot initiation, number of shoots culture-1 and number of shoots elongated culture ${ }^{-1}$. Hence, these two treatments can be considered as the optimum media for in vitro shoot propagation of white marigold. The shoot propagated from axillary bud were found to root well in treatment $\mathrm{T} 5$

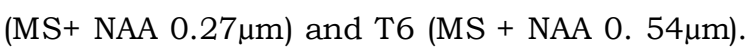
Thus, In vitro propagation of white marigold can be done successfully by inoculating axillary bud explants in T16 (MS + BAP 4.44 $\mu \mathrm{m}+$ IAA 2.84 $\left.\mu \mathrm{m}+\mathrm{GA}_{3} 14.43 \mu \mathrm{m}\right)$ and $\mathrm{T} 11$ (MS + BAP $4.44 \mu \mathrm{m}$ $+\mathrm{GA}_{3} 14.43 \mu \mathrm{m}$ ) for shoot induction and proliferation followed by transferring the shoots to $\mathrm{T} 5(\mathrm{MS}+\mathrm{NAA} 0.27 \mu \mathrm{m})$ for rooting.

Table 1. Effect of different treatments of culture media on four different traits of shoot differentiation

\begin{tabular}{|c|c|c|c|c|c|}
\hline $\begin{array}{l}\text { Sr. } \\
\text { No }\end{array}$ & Treatment (mg 1-1) & $\begin{array}{l}\text { Response of } \\
\text { shoot } \\
\text { initiation } \\
(\%)\end{array}$ & $\begin{array}{l}\text { Days to } \\
\text { shoot } \\
\text { initiation }\end{array}$ & $\begin{array}{l}\text { No. of } \\
\text { shoots } \\
\text { culture-1 }\end{array}$ & $\begin{array}{l}\text { No. of } \\
\text { shoots } \\
\text { elongated } \\
\text { culture-1 }\end{array}$ \\
\hline T1 & $\mathrm{MS}+\mathrm{BAP} 2.22 \mu \mathrm{M}$ & 55.50 & 17.00 & 3.00 & 2.00 \\
\hline T2 & $\mathrm{MS}+\mathrm{BAP} 4.44 \mu \mathrm{M}$ & 45.00 & 16.50 & 4.50 & 3.50 \\
\hline T3 & $\mathrm{MS}+\mathrm{BAP} 8.88 \mu \mathrm{M}$ & 44.50 & 18.00 & 4.45 & 3.20 \\
\hline T4 & $\mathrm{MS}+\mathrm{BAP} 2.22 \mu \mathrm{M}+\mathrm{IAA} 1.42 \mu \mathrm{M}$ & 67.50 & 16.00 & 4.75 & 2.50 \\
\hline T5 & MS+ BAP $2.22 \mu \mathrm{M}+$ IAA $2.84 \mu \mathrm{M}$ & 62.00 & 16.50 & 4.85 & 3.85 \\
\hline T6 & MS+BAP $4.44 \mu \mathrm{M}+$ IAA $1.42 \mu \mathrm{M}$ & 61.00 & 20.00 & 5.25 & 3.60 \\
\hline T7 & MS+BAP $4.44 \mu \mathrm{M}+\mathrm{IAA} 2.84 \mu \mathrm{M}$ & 67.00 & 19.00 & 3.50 & 3.00 \\
\hline T8 & MS+BAP $8.88 \mu \mathrm{M}+\mathrm{IAA} 1.42 \mu \mathrm{M}$ & 56.00 & 22.00 & 4.10 & 2.40 \\
\hline T9 & $\mathrm{MS}+\mathrm{BAP} 8.88 \mu \mathrm{M}+\mathrm{IAA} 2.84 \mu \mathrm{M}$ & 53.00 & 22.50 & 3.30 & 2.35 \\
\hline $\mathrm{T} 10$ & $\mathrm{MS}+\mathrm{BAP} 2.22 \mu \mathrm{M}+\mathrm{GA}_{3} 14.43 \mu \mathrm{M}$ & 81.00 & 9.07 & 4.75 & 3.10 \\
\hline T11 & $\mathrm{MS}+\mathrm{BAP} 4.44 \mu \mathrm{M}+\mathrm{GA}_{3} 14.43 \mu \mathrm{M}$ & 99.00 & 14.59 & 7.34 & 4.92 \\
\hline T12 & $\mathrm{MS}+\mathrm{BAP} 8.88 \mu \mathrm{M}+\mathrm{GA}_{3} 14.43 \mu \mathrm{M}$ & 72.50 & 8.25 & 6.57 & 4.57 \\
\hline T13 & $\mathrm{MS}+\mathrm{BAP} 2.22 \mu \mathrm{M}+\mathrm{IAA} 1.42 \mu+\mathrm{GA}_{3} 14.43 \mu \mathrm{M}$ & 71.00 & 9.79 & 5.65 & 4.06 \\
\hline T14 & $\mathrm{MS}+\mathrm{BAP} 2.22 \mu \mathrm{M}+\mathrm{IAA} 2.84 \mu \mathrm{M}+\mathrm{GA}_{3} 14.43 \mu \mathrm{M}$ & 82.00 & 15.38 & 3.88 & 3.19 \\
\hline T15 & $\mathrm{MS}+\mathrm{BAP} 4.44 \mu \mathrm{M}+\mathrm{IAA} 1.42 \mu \mathrm{M}+\mathrm{GA}_{3} 14.43 \mu \mathrm{M}$ & 71.50 & 7.79 & 6.15 & 4.00 \\
\hline T16 & MS+BAP $4.44 \mu \mathrm{M}+\mathrm{IAA} 2.84 \mu \mathrm{M}+\mathrm{GA}_{3} 14.43 \mu \mathrm{M}$ & 99.50 & 12.07 & 7.80 & 4.94 \\
\hline T17 & $\mathrm{MS}+\mathrm{BAP} 8.88 \mu \mathrm{M}+\mathrm{IAA} 1.42 \mu \mathrm{M}+\mathrm{GA}_{3} 14.43 \mu \mathrm{M}$ & 71.00 & 9.00 & 5.34 & 3.92 \\
\hline \multirow[t]{3}{*}{$\mathrm{T} 18$} & $\mathrm{MS}+\mathrm{BAP} 8.88 \mu \mathrm{M}+\mathrm{IAA} 2.84 \mu \mathrm{M}+\mathrm{GA}_{3} 14.43 \mu \mathrm{M}$ & 76.00 & 9.84 & 5.00 & 3.75 \\
\hline & SEm \pm & 2.28 & 0.87 & 0.34 & 0.23 \\
\hline & CD (5\%) & 6.80 & 2.61 & 1.03 & 0.68 \\
\hline
\end{tabular}


Table 2. Effect of different treatments of culture media on different traits of root differentiation

\begin{tabular}{|l|l|l|l|}
\hline Tr.No & Treatment (mg 1-1) & $\begin{array}{l}\text { Response of } \\
\text { root } \\
\text { initiation (\%) }\end{array}$ & $\begin{array}{l}\text { Days to root } \\
\text { initiation }\end{array}$ \\
\hline T1 & MS + IAA 0.27 $\mu \mathrm{M}$ & 52.50 & 8.02 \\
\hline T2 & MS + IAA 0.54 $\mu \mathrm{M}$ & 42.50 & 6.52 \\
\hline T3 & MS + IBA 0.27 $\mu \mathrm{M}$ & 43.50 & 9.69 \\
\hline T4 & MS + IBA 0.54 $\mu \mathrm{M}$ & 57.50 & 11.19 \\
\hline T5 & MS + NAA 0.27 $\mu \mathrm{M}$ & 81.00 & 5.55 \\
\hline T6 & MS + NAA 0.54 $\mu \mathrm{M}$ & 68.50 & 5.92 \\
\hline & SEm \pm & $\mathbf{3 . 7 5}$ & $\mathbf{0 . 7 8}$ \\
\hline & $\mathbf{C D ( \% )}$ & $\mathbf{1 3 . 6 2}$ & $\mathbf{2 . 8 4}$ \\
\hline
\end{tabular}

\section{References:-}

Belarmino. M. M., T. Abe and T. Sasahara, 1992. Callus induction and plant regeneration in African marigold (Tagetes erecta L.) Jap. J. Breed. 42: 835-841.

Bespalhok, J. C. and K. Hattori, 1998. Friable embryogenic callus and somatic embryo formation from cotyledon explants of African marigold (Tagetes erecta L.). Plant Cell Rep. 17:870-875.

Bhargava, B., B. S. Dilta, Y. C. Gupta, S. R. Dhiman and M. Modgil, 2013. Studies on micropropagation of gerbera. Indian J. Applied Res. 3(11):8-11.

Chakrabarty, D., A. K. A. Mandal and S. K. Datta, 2000. Retrievel of new coloured chrysanthemum through organogenesis from sectorial chimera. Curr. Sci. 78:1061-2000.

Delgado, V. F. A. R. Jimenez and O. ParedesLopez, 2000. Natural pigments: carotenoids, anthocyanins and betalains- Characteristics, biosynthesis, processing and stability. Crit. Rev. Food Sci. Nut. 40: 173-289.

Kothari, S. L. and N. Chandra, 1984. In vitro propagation of African marigold. Hort. Sci. 19: 703-305.
Misra, P. and S. K. Datta, 1999. In vitro propagation of white marigold ((Tagetes erecta L.) through shoot tipe proliferation. Curr. Sci. 77:1138-1140.

Misra, P. and S. K. Datta, 2001. Direct differentiation of shoot buds in leaf segments of white marigold (Tagetes erecta L.). In Vitro Cell. Dev. Biol.-Plant 37:466-470.

Sekioka, E. and R. W. Langham, 1981. Abnormalities in Chrysanthemum regenerated from long term cultures. Ann.Bot.48:559-568.

Son,N.V., A. N. Mokashi, R. V. Hegde, V. S. Patil and $\mathbf{S}$. Lingaraju, 2011. Response of gerbera varieties to micropropagation. Karnataka J. agric. Sci. 24(3):354-357.

Vanagas, P. E., C. H. Andres, M. A. Elena Valverde and O. P. Lopez, 2002. Plant regeneration via organogenesis in marigold. Plant Cell Tissue and Organ Culture, 69:279283.

Vasudevan, P., S. Kashyap and S. Sharma, 1977. Tagetes: A multipurpose plant. Bioresource Technol. 62: 29-35. 